\title{
Theoretical background for the development of stationary process of grain mass threshing with a combine harvester
}

\author{
Alexander P. Lovchikov ${ }^{1}$ and Igor I. Ognev ${ }^{2, *}$ \\ ${ }^{1}$ Federal state budgetary educational institution of higher education «South Ural state agrarian \\ University», Chelyabinsk, Russia \\ ${ }^{2}$ Federal State Autonomous Educational Institution of Higher Education «Ural Federal University \\ named after the first President of Russia B.N. Yeltsin», Ekaterinburg, Russia
}

\begin{abstract}
The article considers the issue that further improvement of the grain combine design with the classical threshing-separating device is possible due to the development of its technological scheme based on the principle of modular construction and stationary process of threshing grain mass. To achieve this goal, the problems were solved, by which laws were revealed and a mathematical description of the technological process of the combine harvester was given, as well as patterns characterizing the effect of straw on the process of grain mass threshing were revealed. In the course of research and evaluation of the effectiveness of the combine harvester's usage the basic laws characterizing the technological process of combine harvester with the classical threshing-separating device are established. The change of the working speed of the combine depends on the technological properties of grain crops. It is revealed that the coefficient of solomitol grain mass $\delta c$ is possible to reduce during combining grain crops through the application of high-cut stems. It was found that with the increase in the height of the cut of the stems (wheat) from 0.10 to $0.20 \mathrm{~m}$, the coefficient of straw content of the grain mass decreases from 0.726 to 0.578 . The additional material of experimental studies to determine the coefficient of straw content of the grain mass $\delta \mathrm{c}$ depending on the diameter and length of the pinned part of the stem is presented. When harvesting grain crops by the method of combing, a grain-bearing mass is formed, which is characterized by a random ratio of the fractions of the straw of the stalk of the annular part. The chaotic structure of plant parts temosolomida mass poses new challenges to supply it in the threshing machine combine harvester with a classic threshingseparating device.
\end{abstract}

\footnotetext{
*Corresponding author: ognev.i.i@yandex.ru
} 


\section{Introduction}

In works [1-2], it is noted that a combine harvester with a classic threshing and separating device (TSD) is a set of technological modules, whose further improvement is possible on basis of a modular construction principle and a stationary process of grain mass threshing.

The studies were carried out to justify theoretical premises of the stationary process of grain mass threshing in a classic (rasp-bar) TSD of a combine harvester.

To achieve this goal, it was planned to solve the following problem: to reveal patterns describing the technological process of a combine harvester and the object of technological impact.

\section{Methodology and materials}

The studies are based on the accepted provisions of a general logical method, system analysis and mathematical analysis methodology.

\section{Results and its discussion}

A combine harvester as a complex multi-parameter transforming technical system [1-2] consists of various technical and technological subsystems. These subsystems include models of individual processes and their relationships, which are characterized by different structures, and therefore hierarchy. The hierarchy means that there are basic (main) and auxiliary (secondary) subprocesses.

During a technological process with a combine harvester, the input influences in the form of operating conditions $X(\mathrm{Tg})$ are converted into the output influences $Y(\mathrm{Tg})$, which determine quantitative and qualitative indicators of the machine. In a combine harvester, the technical subsystems are basically sequentially connected technological subprocesses performed by technical devices of the combine: grain mowing; selection of grain mass swaths; grain mass threshing; grain heap separation; coarse heap separation; chopping and scattering or swathing, or straw gathering. Based on this, the technological process of a combine can be presented in the form of a model built on the 'input-output' principle.

At the input of the model, vector function $X$ of the operating conditions (external influences) is applicable:

$$
X=\left(Y_{\mathrm{p}}(t), \omega_{3}(t), \omega_{\mathrm{c}}(t), \quad 3_{\mathrm{c}}(t), K_{\mathrm{n}}(t), B_{\mathrm{c}}(t)\right),
$$

where $y_{\mathrm{p}}(t)$ is grain yield, t/ha; $\omega_{3}(t)$ and $\omega_{\mathrm{c}}(t)$ is grain and straw moisture, \%; $3_{\mathrm{c}}(t)$ is weediness of crops, \%; $K_{\Pi}(t)$ is droopiness of crops; $E_{\mathrm{c}}(t)$ is botanical sort of a crop.

As an output variable, the vector function of qualitative and quantitative indicators of a combine harvester's technological process is taken:

$$
Y=\left(V_{\mathrm{p}}(t), W_{4}(t), q_{\text {уд }}(t), \Pi_{3}(t), K_{\text {пз }}(t), h P_{\mathrm{c}}(t), B C_{\mathrm{c}}(t)\right),
$$

where $V_{\mathrm{p}}(t)$ is combine's working speed, $\mathrm{m} / \mathrm{s} ; W_{u}(t)$ is combine's hourly productivity, ha/h; $q_{\text {уд }}(\mathrm{t})$ is specific fuel consumption, $\mathrm{kg} / \mathrm{ha} ; \Pi_{3}(t)$ is grain loss; $K_{\text {пз }}(t)$ are grain quality indicators; $h P_{\mathrm{c}}(t)$ are quantitative indicators of chopping and scattering of straw; 
$B C_{\mathrm{c}}(t)$ is swathing or gathering of straw.

The output indicators of the combine harvester's technological process functioning can conditionally be divided into two types - integral and differential.

Integral indicators are those that are formed due to combination of transforming technical subsystems. These include such indicators as $V_{\mathrm{p}}, W_{ч}, q_{\text {уд }}, \Pi_{3}, K_{\text {пз }}$.

Differential indicators are those that formed because of the action of individual transforming technical subsystems. This type can include indicators characterizing chopping and scattering of straw in the field, swathing or collection of straw in the field, grain loss behind a pick-up or a cutter (header).

It is well known [1-3] that the hourly productivity of a combine harvester depends on the working speed of the machine and the width of the cutter (header), which is determined from the following ratio:

$$
B_{\text {Ж }}=\frac{q}{V_{\mathrm{K}} \cdot \mathrm{y}_{3}\left(1+\delta_{\mathrm{c}}\right)},
$$

where $B_{\text {ж }}$ is width of the cutter; m;

$q$ is the thresher's output, $\mathrm{kg} / \mathrm{s}$;

$V_{\mathrm{K}}$ is the combine's working speed, $\mathrm{m} / \mathrm{s}$;

$\mathrm{y}_{3}$ is grain mass yield by grain, $\mathrm{kg} / \mathrm{m}^{2}$;

$\delta_{\mathrm{c}}$ is the coefficient characterizing strawiness of grain mass. During harvesting of grain crops, regardless of the method, in addition to productive plants, there are also unproductive (weed) crops, and fluctuations in the feeding of grain mass into the threshing machine of a combine take place. Then the output of a classic threshing machine of the combine equals

$$
q=0.6 \cdot q_{\text {п }}\left(1+\frac{1-\varepsilon}{\delta_{\mathrm{c}}+\varepsilon}\right) \cdot \chi,
$$

where $q_{\Pi}$ is passport output of the combine's thresher, $\mathrm{kg} / \mathrm{s}$;

$\varepsilon$ - is the coefficient characterizing the grain mass' weediness;

$\chi$ is the coefficient taking into account the effect of fluctuations of grain mass' feed on the output of the thresher.

Based on expressions (3) and (4), after all transformations, we will obtain:

$$
V_{\mathrm{K}}=\frac{0.6 \cdot q_{\mathrm{\Pi}}\left(1+\frac{1-\varepsilon}{\delta_{\mathrm{C}}+\varepsilon}\right) \cdot \chi}{\mathrm{B}_{\varkappa} \cdot \mathrm{V}_{3}\left(1+\delta_{\mathrm{c}}\right)} .
$$

The results of the analysis of expression (5) indicate that increase in the working speed of the combine $V_{\mathrm{K}}$ is more intensively affected by the grain mass strawiness factor (coefficient $\delta_{\mathrm{c}}$ ). The value of strawiness coefficient $\delta_{\mathrm{c}}$ is determined by the ratio of grain $m_{3}$ and straw $m_{\mathrm{c}}$ by weight.

During crop harvesting with a combine harvester, the grain mass of a head $m_{3}$ can be considered as a constant, that is $m_{3}=$ const. Then the ratio of grain and straw by weight as a technological property of grain crops, expressed through strawiness coefficient $\delta_{c}$, is determined primarily by the plants' length.

In works [3,4], it is noted that the value of the grain mass strawiness coefficient $\delta_{\mathrm{c}}$ can be reduced during harvesting of crops through undertopping of stems. It is established that with an increase in the cutting height (Omskaya 36 wheat) from 0.10 to $0.20 \mathrm{~m}$, the value of the grain mass strawiness coefficient decreases from 0.726 to 0.578 , which makes it possible to increase the working speed of the combine by $40.2-58.5 \%$.

Besides, science and practice [5-9] found out that it is possible to minimize the influence of the ratio of grain to straw by weight on the output of the combine's threshing machine due to the combing method when harvesting grain crops. Since in this case the grain mass contains up to 
$80.0 \%$ of free grain and $20.0 \%$ of plant part [5-9] and is characterized by a new technological state as grain-straw mass. The plant part consists of head residues and the prickly part of the stem, which varies in length due to the peculiarity of the process of separating the head from the stem by the combing method, the physicomechanical properties of the plant, and the stem's diameter.

Experimental studies have shown that the diameter of the stem of the prickly part, for example, of Omskaya 36 wheat, differs significantly from the diameter at the base and in the middle of the stem. When changing the height of the stem from $0.10 \mathrm{~m}$ to $0.55 \mathrm{~m}$, the difference is the following: base $-2.81 \mathrm{~mm}$ (100.0\%); middle part - $2.24 \mathrm{~mm}$ (79.7\%); prickly part - 1.35 $\mathrm{mm}(48.0 \%)$.

Based on this fact, we conducted additional experimental studies to determine the value of the grain mass strawiness coefficient $\delta_{c}$ depending on the length of the prickly part of the stem, which is reflected in Table 1.

Table 1. The change in the grain-straw mass strawiness coefficient.

\begin{tabular}{|l|l|l|l|l|l|l|}
\hline \multirow{2}{*}{ Test No.* } & \multirow{2}{*}{$\begin{array}{l}\text { Stem } \\
\text { length, } \mathrm{m}\end{array}$} & \multirow{2}{*}{$\begin{array}{l}\text { Grain mass strawiness } \\
\text { coefficient } * *\end{array}$} & & \multicolumn{4}{|l|}{ Length of the stem's prickly part $l_{\text {пкс }}, \mathrm{m}$} \\
\cline { 4 - 7 } & & & $\bar{\chi}$ & $\bar{\chi}$ & $\bar{\chi}$ & $\bar{\chi}$ \\
\hline 1 & 0.8 & 0.66 & 0.36 & 0.21 & 0.17 & 0.03 \\
\hline 2 & 0.7 & 0.64 & 0.28 & 0.23 & 0.20 & 0.04 \\
\hline 3 & 0.6 & 0.67 & 0.41 & 0.30 & 0.28 & 0.06 \\
\hline 4 & 0.5 & 0.69 & 0.57 & 0.45 & 0.34 & 0.05 \\
\hline
\end{tabular}

* Commentary: crop - Chelyabinsk wheat 2; grain moisture - 15.9\%; testing site - 'Akbashevsky' $\mathrm{OOO}$;

** Values are obtained from the point of normal stem cutting (cut height $0.12 \mathrm{~m}$ ).

As a result of Table 1 data processing, using the least square method (LSM) and MathCAD 14 program, we obtained the dependences of changes in the grain mass strawiness coefficient $\delta_{\mathrm{c}}$ on the length of the stem's prickly part:

$$
\begin{gathered}
\delta_{\mathrm{c}}=0.947 \cdot l_{\text {пкс }}+0.034 \text {; when } l_{\text {ст }}=0.8 \mathrm{~m} ; \\
\delta_{\text {с }}=0.75 \cdot l_{\text {пкс }}+0.075 \text {; when } l_{\text {ст }}=0.7 \mathrm{~m} ; \\
\delta_{\mathrm{c}}=-2.75 \cdot l_{\text {пкс }}^{2}+1.895 \cdot l_{\text {пкс }}+0.075 \text {; when } l_{\text {ст }}=0.6 \mathrm{~m} ; \\
\delta_{\mathrm{c}}=-4.25 \cdot l_{\text {пкс }}^{2}+2.945 \cdot l_{\text {пкс }}+0.06 \text {; when } l_{\text {ст }}=0.5 \mathrm{~m},
\end{gathered}
$$

where $l_{\text {пкс }}$ is the length of the stem's prickly part, $l_{\text {пкс }} \in(0-0.3) \mathrm{m}$.

When the length of the prickly part of the stem equals zero $\left(l_{\text {пкс }}=0 \mathrm{~m}\right)$, the value of the grain mass strawiness coefficient $\delta_{\mathrm{c}}$ changes according to the formula:

$$
\delta_{\mathrm{c}}=d \cdot l_{\mathrm{cT}}+e,
$$

where $\quad l_{\text {ст }}$ is the stem's length, $l_{\text {ст }} \in(0,50-0.80) \mathrm{m}$;

$d$ and $e$ are coefficients (constant and free member), $d=-0.08 \mathrm{~m}^{-1}$ and $e=0.097$.

The grain-straw mass as an object of technological impact is characterized by a random ratio of the fractions of the stem straws of the prickly part along the length. Therefore, the grain-straw mass strawiness coefficient $\delta_{c}$ in this case is not a poinwise, but a weighted average value:

$$
\delta_{\mathrm{c}}=\frac{m_{0}+m_{0,1}+m_{0,2}+m_{0,3}}{m_{3}+\left(m_{0}+m_{0,1}+m_{0,2+m_{0,3}}\right)},
$$

where

$m_{3}$ is the grain mass, $\mathrm{g}$; 
$m_{0}$ is the mass of the plant part's fine fraction, g;

$m_{0,1}$ is the plant part's fraction mass with the length $l_{\text {пкс }}=0.10 \mathrm{~m}$;

$m_{0,2}$ is the plant part's fraction mass with the length $l_{\text {пкс }}=0.20 \mathrm{~m}$;

$m_{0,3}$ is the plant part's fraction mass with the length $l_{\text {пкс }}=0.30 \mathrm{~m}$;

A random nature of the length formation of the stem's prickly part will lead to an uneven feed of the grain-straw mass into the combine's threshing machine, which will ultimately affect the grain quality indicators. It is found that with an increase in the unevenness of the grain-straw mass feed into the threshing machine of the combine, an increase in grain crushing $\left(D_{3}, \%\right)$ is observed in accordance with the expression

$$
D_{3}=0.001 \cdot V^{2}+0.025 \cdot V+0.92 \text {, }
$$

where $V$ is the uneven feed of grain-straw mass into the combine's threshing machine, $V \epsilon$ $(10.0-40.0) \%$.

\section{Conclusion}

Thus, in order to increase the output capacity of TSD of a combine harvester, and therefore its hourly productivity, it is necessary to minimize the negative impact of such technological properties of grain crops as the ratio of grain to straw by weight. This can be done through the development of a combine cutter in the form of a technological module - a comb cutter. The technological process is characterized by the fact that the grain mass is converted into a new technological state - the grain-straw mass because of the reduction of the plant part's proportion. This object of technological impact is characterized by a chaotic spatial arrangement of the plant part's remains in the form of a prickly part of the stem. Therefore, in the future it is necessary to develop new approaches to the issue of feeding grain-straw mass into the classic threshing machine of a combine harvester.

\section{References}

1. To the development of a stationary process of threshing grain mass combine with a classic threshing and separating device. To the development of a stationary process of threshing grain mass combine with a classic threshing and separating device / Ryadnov A.I., Lovchikov A.P., Shagin O.S., Shahov V.A. // Izvestiya Nizhnevolzhskogo agrouniversitetskogo kompleksa: nauka i vysshee professional'noe obrazovanie, № 2 (54), 2019, Volgogradskij GAU, Volgograd, 2019. - P. 314-322. doi: 10.32786/20719485-2019-02-37.

2. Methodical approach to the modeling of the technological process of combine harvester / Lovchikov A.P., Pozdeev E.A., Shagin O.S., Shahov V.A., Hlopko Y.A., Yuhin G.P. // Izvestiya OGAU, № 6 (74). Publishing center of OGAU, Orenburg, 2018. P. 91-93.

3. The results of the production inspection of direct harvesting with a high grain crop cut / Lovchikov A.P., Lovchikov V.P., Iksanov SH.S., Shagin O.S. // Izvestiya OGAU. № 1 (63). Orenburg, 2017. P. $75-77$.

4. High cross - section-an affordable alternative to the reapers of the comb on the root [Electronic resource]. http://www.agroru.com

5. Aldoshin, N.V. Cleaning legumes method flock [Text] / N.V. Aldoshin, N.A. Lylin, M.A. Mosyakov // «Dal'nevostochnyj agrarnyj vestnik», 2017. №1 (41). P. 67-74.

6. Aldoshin N.V., Mosyakov M.A. Improving the design of the combing device for harvesting of leguminous crops. Vestnik FGBOU VPO «Moskovskij gosudarstvennyj 
agroinzhenernyj universitet imeni V.P. Goryachkina». 2018. № 2 (84). - P. 23-27.

7. Bur'yanov, M.A. Development and improvement of methods of substantiation of technology of combine harvesting of grain crops by combing [Text] / M.A. Bur'yanov, A.I. Bur'yanov, I.V. Chervyakov, Y.O. Goryachev // «Vestnik agrarnoj nauki Dona». 2017. № 38. P. 59-72.

8. Byshov, N.V. Machine for harvesting grain crops [Text] / N.V. Byshov, A.I. Ryadnov, O.A. Fedorova // «Izvestiya Nizhnevolzhskogo agrouniversitetskogo kompleksa: nauka i vysshee professional'noe obrazovanie». $2018 . \quad № 1 \quad$ (49). P. 220-227.

9. Bur'yanov, A.I. Method and means of harvesting grain crops with the separation of the pile on the constant place [Text] / A.I. Bur'yanov, S.G. Zajcev, I.V. Chervyakov // «Politematicheskij setevoj elektronnyj nauchnyj zhurnal Kubanskogo gosudarstvennogo agrarnogo universiteta». 2018. № 140. P. 1-16. 